\section{Smooth Crabgrass Control in Perennial Ryegrass and Creeping Bentgrass Tolerance to Quinclorac}

\author{
Peter H. Dernoeden', Cale A. Bigelow, John E. Kaminski, and \\ John M. Krouse \\ Department of Natural Resource Sciences and Landscape Architecture, \\ University of Maryland, College Park, MD 20742-5821
}

Additional index words. Digitaria ischaemum, herbicide, micronutrients, nitrogen, phytotoxicity, postemergence

\begin{abstract}
Smooth crabgrass [Digitaria ischaemum (Schreber) Schreber ex Muhlenb.] is an invasive weed of cool-season turfgrasses. Previous research has demonstrated that quinclorac is an effective postemergence herbicide for crabgrass control, but performance has been erratic in some regions. Furthermore, quinclorac may elicit objectionable levels of discoloration in creeping bentgrass (Agrostis stolonifera $\mathbf{L}$.). The objectives of this 3-year field study were to determine optimum rates and timings of quinclorac applications that provide consistent levels of effective crabgrass control and to assess creeping bentgrass quality responses to quinclorac. To evaluate crabgrass control, quinclorac was applied in early-, mid-and late-postemergence timings at various rates to a perennial ryegrass (Lolium perenne L.) turf. Similar treatments were applied to creeping bentgrass to determine if application timing and rate influenced the level and duration of discoloration. Quinclorac was applied alone or was tank-mixed with either urea $\left(\mathrm{N}\right.$ at $6.1 \mathrm{~kg}^{\left.\cdot \mathbf{h a}^{-1}\right)}$ or chelated iron $(\mathrm{Fe})+$ nitrogen $(\mathrm{N})\left(\mathrm{FeSO}_{4}\right.$ at $1.1 \mathrm{~kg} \cdot \mathrm{ha}^{-1}+\mathrm{N}$ at $\left.2.2 \mathrm{~kg} \cdot \mathrm{ha}^{-1}\right)$ to determine if they would mask discoloration. Crabgrass control generally was more effective in the early- and midpostemergence application timings. A single application of quinclorac $\left(0.84 \mathrm{~kg} \cdot \mathrm{ha}^{-1}\right)$ was effective where crabgrass levels were moderate, but sequential (i.e. multiple) applications were required where crabgrass levels were severe. The most consistent level of crabgrass control where weed pressure was severe occurred with three, sequential quinclorac $(0.37$ or $0.42 \mathrm{~kg} \cdot \mathrm{ha}^{-1}$ ) applications. Creeping bentgrass exhibited 2 to 11 weeks of unacceptable discoloration in response to sequential quinclorac applications. Chelated $\mathrm{Fe}+\mathrm{N}$ was more effective than urea in masking discoloration. In general, chelated $\mathrm{Fe}+\mathrm{N}$ tank-mixed with quinclorac masked discoloration and turf had quality equivalent to untreated bentgrass on most, but not all rating dates. Chemical names used: 3,7,-dichloro-8-quinolinecarboxylic acid (quinclorac).
\end{abstract}

Smooth crabgrass [Digitaria ischaemum (Schreber) Schreber ex Muhlenb.] is among the most common and invasive weeds in turfgrasses in many regions of the United States. Turfgrass managers commonly apply preemergence herbicides to provide seasonlong crabgrass control. Poorly timed applications or unseasonably wet weather, however, may reduce the efficacy of these herbicides (Dernoeden, 2001; Martin and Sullivan, 1996). When poor crabgrass control occurs, postemergence herbicide applications may be necessary. Previous research has shown that smooth crabgrass can be effectively controlled with several postemergence herbicides, but the efficacy among products can vary from year to year and among regions (Chism and Bingham, 1991; Dernoeden and Krouse, 1990; Enache and Ilnicki, 1991; Johnson, 1975).

Received for publication 24 May 2002. Accepted for publication 9 Dec. 2002. Contribution of the Maryland Agricultural Experiment Station, College Park, MD 20742. We are grateful for the financial support of this study provided by BASF Corp. and the United States Golf Association.

${ }^{1}$ To whom reprint requests should be addressed. E-mail address: pd9@umail.umd.edu
Currently, there are few herbicides that can be safely applied to creeping bentgrass to control annual grassy weeds postemergence. Quinclorac is labeled for use in creeping bentgrass, and has been shown to effectively control crabgrass in other cool-season turfgrass species (Bhowmik and O'Toole, 1991; Chism and Bingham, 1991; Dernoeden and Krouse, 1990; Enache and Ilnicki, 1991; Johnson, 1994a, 1994b; Reicher et al., 1999). In a Maryland study, quinclorac effectively controlled crabgrass in a single application $(0.84$ $\mathrm{kg} \cdot \mathrm{ha}^{-1}$ ) in 2 out of 3 years where crabgrass pressure was moderately severe (Dernoeden, 2001). In another Maryland study, however, multiple applications of quinclorac were required to achieve commercially successful control under high crabgrass pressure (Dernoeden and Krouse, 1990).

The safety of quinclorac on cool-season grasses has been inconsistent, especially on turf maintained at low mowing heights. For example, quinclorac $\left(0.84 \mathrm{~kg} \cdot \mathrm{ha}^{-1}\right)$ caused significant injury 2 weeks after a mid- June application to a Kentucky bluegrass (Poa pratensis L.) fairway in Georgia (Johnson, 1994a). In Virginia, quinclorac was deemed relatively safe with only slight Kentucky bluegrass injury observed when the herbicide was applied in mid-July at 0.56 or $1.12 \mathrm{~kg} \cdot \mathrm{ha}^{-1}$ (Chism and Bingham, 1991). Quinclorac was safe on Kentucky bluegrass, perennial ryegrass and tall fescue (Festuca arundinacea Schreb.), regardless of rate $\left(0.84\right.$ to $\left.2.24 \mathrm{~kg} \cdot \mathrm{ha}^{-1}\right)$ or timing (preemergence, early-postemergence or late-postemergence) over a 4-year period in New Jersey (Enache and Ilnicki, 1991). Quinclorac ( 0.56 to $\left.0.84 \mathrm{~kg} \cdot \mathrm{ha}^{-1}\right)$ also was reported to be safe to 'Penncross' creeping bentgrass grown on a Massachussetts nursery green (Bhowmik and O'Toole, 1991). On a 'Penncross' bentgrass green in Georgia, however, quinclorac applied in early-June at $0.6 \mathrm{~kg} \cdot \mathrm{ha}^{-1}$ severely reduced quality and cover for $\geq 8$ weeks (Johnson, 1994b). Similar results were reported on a creeping bentgrass green in New Jersey (Sciarappa, 1991). Reicher et al. (2002), reported that quinclorac $\left(0.84 \mathrm{~kg} \cdot \mathrm{ha}^{-1}\right)$ applied either pre-plant, or 14 or $28 \mathrm{~d}$ after creeping bentgrass seedling emergence caused significant ground cover reductions to spring seeded bentgrass in North Carolina, but not in Indiana or Iowa. It was suggested in the aforementioned study that caution should be exercised when using quinclorac where soil organic matter is low $(<2 \%)$ or in regions where elevated temperatures may occur early in the year. Similarly, Evans et al. (1992) reported that quinclorac can be more damaging to young turfgrasses grown on soils containing low organic matter.

Injury to creeping bentgrass turf sometimes can be ameliorated by tank-mixing herbicides with safeners, such as $\mathrm{N}$ or chelated $\mathrm{Fe}+\mathrm{N}$. For example, slow release liquid $\mathrm{N}$ and a $\mathrm{Fe}+\mathrm{N}$ product helped to mask the injurious effects of fenoxaprop-ethyl $\{(+/-)-2-[4-[(6-$ chloro-2benzoxazolyl)oxy]-phenoxy]propanoic acid\} applied to creeping bentgrass (Dernoeden, 1989). A similar effect was observed with quinclorac applied with Fe to creeping bentgrass in New Jersey (Sciarappa, 1991). In contrast, chelated Fe tank-mixed with quinclorac had no effect on creeping bentgrass color in a Massachussetts study (Bhowmik and O'Toole, 1991). Although quinclorac is effective for postemergence crabgrass control in many regions, the optimum rate and time of application have not been well defined for the mid-Atlantic region, and its effects on bentgrass quality have been erratic. Therefore, the objectives of this study were to assess the effects of several quinclorac rates applied in three timings for postemergence crabgrass control in perennial ryegrass and to evaluate creeping bentgrass injury in response to quinclorac.

\section{Materials and Methods}

A 3-year field study was conducted at Univ. of Maryland turfgrass research facilities in Silver Spring, Md. (2000) and College Park, Md. (2001 and 2002). Soil at the Silver Spring site was a Sassafras sandy loam (fineloamy, siliceous, mesic Typic Hapludult) with a $\mathrm{pH}$ of 6.8 and $36 \mathrm{mg}$ organic matter/g soil. Soil at the College Park site was a Keyport silt loam (fine, mixed, semiactive, mesic Aquic Hapludult) with a $\mathrm{pH}$ of 6.5 and $12 \mathrm{mg}$ of organic matter/g soil. 


\section{Turf Management}

Crabgrass control. Crabgrass control was assessed in mature stands of perennial ryegrass. The study areas were mowed twice weekly to a height ranging between $3.8 \mathrm{~cm}$ and $5.0 \mathrm{~cm}$ and the clippings were returned. Smooth crabgrass pressure was severe in the 2000 site. In 2001, efficacy was assessed on two sites that were either moderately infested or severely infested with smooth crabgrass. A moderate infestation of crabgrass was judged to be between $40 \%$ and $60 \%$ crabgrass cover at the end of the study in untreated control plots; whereas, severe pressure was judged to be $\geq 85 \%$ crabgrass cover. The severely infested site was overseeded with crabgrass in Nov. 1999 and allowed to reseed in 2000; whereas the moderately infested site was overseeded in Nov. 2000 and treated in 2001. Crabgrass seed for both 2001 sites was collected from the Silver Spring facility and broadcast in clippings at an unknown rate. In 2002, a site adjacent to the 2001 study area was utilized and crabgrass pressure was severe. All three sites received $\mathrm{N}$ from urea at $100 \mathrm{~kg} \cdot \mathrm{ha}^{-1}$ in autumn. No spring or summer fertilizer was applied in 2000, but the 2001 and 2002 study areas received $\mathrm{N}$ from urea at $49 \mathrm{~kg} \cdot \mathrm{ha}^{-1}$ in June of both years. Due to frequent rain during 2000 , the area required infrequent irrigation. In 2001 and 2002, however, the study areas were irrigated frequently to prevent drought stress.

There were three application timings in 2000 and 2001: early-postemergence (EPO), mid-postemergence (MPO) and late-postemergence, (LPO); and three quinclorac rates: 0.84 $\mathrm{kg} \cdot \mathrm{ha}^{-1}$ applied once, $0.56+0.56 \mathrm{~kg} \cdot \mathrm{ha}^{-1}$ applied twice on a 4-week interval and $0.42+0.42+0.42$ (2000) or $0.37+0.37+0.37$ (2001) $\mathrm{kg} \cdot \mathrm{ha}^{-1}$ applied three times on a 2 -week interval. The $0.42 \mathrm{~kg} \cdot \mathrm{ha}^{-1}$ sequential rate was reduced to $0.37 \mathrm{~kg} \cdot \mathrm{ha}^{-1}$ in 2001 to meet label restrictions requiring $\leq 1.12 \mathrm{~kg} \cdot \mathrm{ha}^{-1}$ of quinclorac being applied per year. In 2002, all treatments were applied MPO at the following rates: $0.84 \mathrm{~kg} \cdot \mathrm{ha}^{-1}$ applied once; $0.56+0.56 \mathrm{~kg} \cdot \mathrm{ha}^{-1}$ applied twice on a 2 -week interval; and $0.37+0.37+0.37$ $\mathrm{kg} \cdot \mathrm{ha}^{-1}$ applied three times on a 2-week interval. Application dates are shown in Table 1. The percent of plot area covered by smooth crabgrass was assessed visually on a $0 \%$ to $100 \%$ scale, where $0=$ no crabgrass and $100=$ entire plot area covered with crabgrass. Treatments with mean smooth crabgrass cover ratings exceeding $5 \%$ of plot area covered were considered to be commercially unacceptable.

Bentgrass injury. Treatments were applied to either a mature stand of 'Penncross', 'Crenshaw', or 'L-93' creeping bentgrass in 2000, 2001, and 2002, respectively. All bentgrass sites were mowed to a height ranging between 1.3 and $1.5 \mathrm{~cm}$ three times per week and clippings were removed. The Silver Spring site received $\mathrm{N}$ from urea at $100 \mathrm{~kg} \cdot \mathrm{ha}^{-1}$ in Autumn 1999, but no fertilizer was applied in 2000. The College Park sites received N from urea at $147 \mathrm{~kg} \cdot \mathrm{ha}^{-1}$ in the autumn of 2000 and 2001, but were not fertilized the following spring or summer. Chlorothalonil (tetrachloroisophthalonitrile) and myclobutanil [ $\alpha$-butyl- $\alpha$ (chlorophenyl)-1- $H-1,2,4$, triazole-1-propanenitrile] were applied at

Table 1. Quinclorac rates and dates of application for smooth crabgrass control in perennial ryegrass.

\begin{tabular}{lcccc}
\hline Quinclorac rate & & \multicolumn{3}{c}{ Application dates } \\
\cline { 3 - 5 }$\left({\left.\mathrm{kg} \cdot \mathrm{ha}^{-1}\right)}^{-1}\right.$ & Timing & 2000 & 2001 & 2002 \\
\hline 0.84 & $\mathrm{EPO}^{\mathrm{z}}$ & 1 June & 31 May & --- \\
$0.56+0.56$ & $\mathrm{EPO}$ & 1, 30 June & 31 May, 28 June & --- \\
$0.42+0.42+0.42$ & $\mathrm{EPO}$ & 1,13, 30 June & --- & --- \\
$0.37+0.37+0.37$ & $\mathrm{EPO}$ & -- - & 31 May; 14, 28 June & --- \\
0.84 & MPO & 30 June & 28 June & 21 June \\
$0.56+0.56$ & MPO & 30 June, 27 July & 28 June, 25 July & 21 June, 3 July \\
$0.42+0.42+0.42$ & MPO & 30 June; 13, 27 July & --- & --- \\
$0.37+0.37+0.37$ & MPO & --- & 28 June; 11, 25 July & 21 June; 3, 19 July \\
0.84 & LPO & 27 July & 25 July & --- \\
$0.56+0.56$ & LPO & 27 July, 23 Aug. & 25 July, 21 Aug. & --- \\
$0.42+0.42+0.42$ & LPO & 27 July; 10, 23 Aug. & 25 July; 7, 21 Aug. & --- \\
$0.37+0.37+0.37$ & LPO & --- & -- \\
\hline
\end{tabular}

${ }^{\mathrm{z}}$ Early-postemergence (EPO) applications were initiated when crabgrass was in the 1- to 4-leaf stage.

yTreatment not evaluated.

${ }^{\mathrm{x}}$ Mid-postemergence (MPO) applications were initiated when crabgrass was in the 5-leaf to 3-tiller stage in 2000 and 4-leaf to 3-tiller or 2-leaf to 2-tiller stage for the severe and moderately infested sites, respectively in 2001. In 2002, applications were initiated when crabgrass was in the 3- to 5-leaf stage.

"Late-postemergence (LPO) applications were initiated when crabgrass was in the 4- to 22-tiller stage in 2000 , and 2- to 8-tiller or 2- to 3-tiller stage for the severe and moderately infested sites, respectively in 2001.

recommended rates on 18- to 21-d intervals as needed to control dollar spot (Sclerotinia homoeocarpa F.T. Bennett) in the 'Crenshaw' turf, but fungicides were not needed in the 'Penncross' or 'L-93' turf.

In 2000, quinclorac treatments were identical to those used in the aforementioned perennial ryegrass area. In 2001 and 2002, however, treatments were initiated only in the mid-postemergence timing. In 2001, quinclorac was applied alone or tank-mixed with either urea (N at $6.1 \mathrm{~kg} \cdot \mathrm{ha}^{-1}$ ) or Lesco's 12-0-0 Chelated Fe Plus Micronutients ( $\mathrm{Fe}+\mathrm{N}$; Lesco Co. Sebring, Fla.). In 2002, only $\mathrm{Fe}+\mathrm{N}$ was used as a safener. For the $\mathrm{Fe}+\mathrm{N}$ product, $\mathrm{FeSO}_{4}$ was applied at $1.1 \mathrm{~kg} \cdot \mathrm{ha}^{-1}+\mathrm{N}$ at $2.2 \mathrm{~kg} \cdot \mathrm{ha}^{-1}+\mathrm{S}$ at 0.7 $\mathrm{kg} \cdot \mathrm{ha}^{-1}+\mathrm{Mn}$ at $0.4 \mathrm{~kg} \cdot \mathrm{ha}^{-1}$. An additional urea or $\mathrm{Fe}+\mathrm{N}$ application was made 2 weeks following the last application and again on 31 Aug. 2001 , except for plots treated with quinclorac alone. In 2002, an additional $\mathrm{Fe}+\mathrm{N}$ application without quinclorac was made on 19 July. For comparison, urea and $\mathrm{Fe}+\mathrm{N}$ were applied alone to separate plots in 2001, but not in 2002. The dates of all treatment applications appear in the data tables. Turf color was rated visually on a 0 to 10 scale, where $0=$ turf brown; 7.5 $=$ minimum acceptable discoloration; and 10 = optimum greenness. Turf quality also was rated visually on a 0 to 10 scale, where $0=$ turf brown or dead; $7.5=$ minimum acceptable quality for fairway turf; and $10=$ uniform, optimum green color and density.

All treatments were applied in $467 \mathrm{~L} \cdot \mathrm{ha}^{-1}$ of water using a $\mathrm{CO}_{2}$ pressurized $(262 \mathrm{kPa})$ sprayer equipped with an $8004 \mathrm{E}$ flat-fan nozzle. All quinclorac treatments involved the 75 DG formulation and were tank-mixed with methylated seed oil (MSO, 1\% v/v) and the study sites were irrigated with at least $2 \mathrm{~cm}$ of water within $24 \mathrm{~h}$ of each application. Label instructions require tank-mixing quinclorac with crop oil or MSO $(1 \% \mathrm{v} / \mathrm{v})$ to achieve effective crabgrass control. It was not known if the MSO provided a role in inducing turf discoloration. Therefore, a study was conducted to determine the effects of quinclorac and MSO applied separately to 'Crenshaw' in a site adjacent to that used in 2001.

Experimental design and statistical analysis. For all studies, plot size was $1.5 \times 1.5 \mathrm{~m}$ and treatments were arranged in a randomized complete-block design with four replications per treatment. Data were subjected to the analysis of variance (ANOVA) using the SAS system (SAS Institute, 1996), and treatment means were separated at $P \leq 0.05$ by Fisher's protected least significant difference test (LSD).

\section{Results and Discussion}

Crabgrass control. All quinclorac rates and timings reduced crabgrass cover in 2000 (Table 2). All EPO treatments appeared to provide excellent postemergence crabgrass control $20 \mathrm{~d}$ after initial treatment on 21 June (data not shown). By 21 July, however, recovery of herbicide injured crabgrass and subsequent germination of new crabgrass seedlings were observed in plots treated with 0.84 or $0.56+0.56 \mathrm{~kg} \cdot \mathrm{ha}^{-1}$ of quinclorac. The $0.42+0.42+0.42 \mathrm{~kg} \cdot \mathrm{ha}^{-1}$ quinclorac treatment in the EPO timing provided excellent postemergence and subsequent preemergence control of crabgrass. Commercially unacceptable $(>5 \%)$ crabgrass cover, however, resulted from quinclorac applied at 0.84 and $0.56+0.56 \mathrm{~kg} \cdot \mathrm{ha}^{-1}$ in the EPO timing. For the MPO treatments, poor crabgrass control again was observed with either the 0.84 or $0.56+0.56 \mathrm{~kg} \cdot \mathrm{ha}^{-1}$ rates. The $0.42+0.42+0.42$ $\mathrm{kg} \cdot \mathrm{ha}^{-1}$ sequential applications again provided commercially acceptable crabgrass control. For the LPO treatments, all quinclorac rates appeared to severely injure the crabgrass for several weeks following application and provided a reduction in crabgrass cover, when compared to the untreated control (data not shown). Many injured crabgrass plants, however, recovered, particularly in plots treated with the 0.84 and $0.56+0.56 \mathrm{~kg} \cdot \mathrm{ha}^{-1}$ rates. On the final rating date, data showed that quinclorac applied at $0.42+0.42+0.42 \mathrm{~kg} \cdot \mathrm{ha}^{-1}$ in the LPO timing provided good control $(8 \%$ crabgrass cover) and data were similar to those of the same rate applied in the EPO and MPO timings (Table 2). 
Table 2. Smooth crabgrass cover in perennial ryegrass as influenced by various quinclorac rates and application timings.

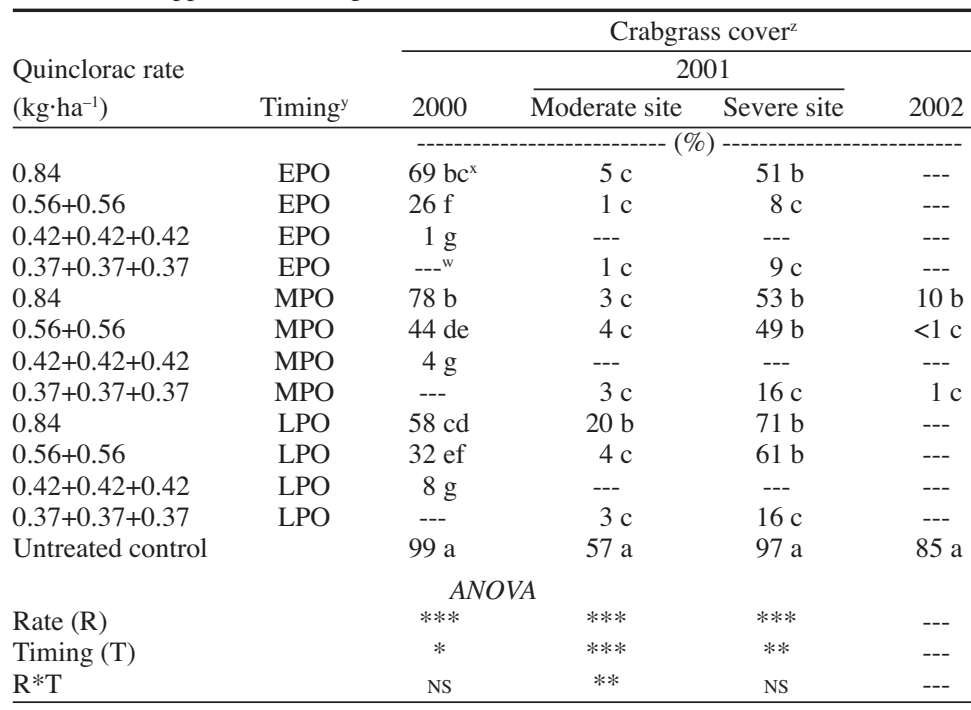

${ }^{2}$ Crabgrass cover was assessed visually on a linear $0 \%$ to $100 \%$ scale, where $0=$ no crabgrass and $100=$ entire plot area covered on 8 Sept., 17 Sept., and 9 Aug. in 2000, 2001 , and 2002, respectively.

${ }^{y}$ Early postemergence $=\mathrm{EPO}$; mid-postemergence $=\mathrm{MPO}$; and late postemergence $=$ LPO. ${ }^{x}$ Means in the same column followed by the same letter are not significantly different according to Fisher's protected least significant difference $(P \leq 0.05)$.

"Treatment not evaluated.

ws $, *, * *, * * *$ Nonsignificant or significant at the $0.05,0.01,0.001$ levels, respectively.

In 2001, crabgrass control was evaluated at two sites containing either moderate or severe crabgrass levels. The severe site was overseeded with crabgrass in Oct. 1999 and allowed to reseed in 2000; whereas, the moderate site was overseeded in 2000 . Hence, the severe site had a larger reservoir of seed, which likely germinated over a longer period of time. The density of crabgrass plants also was extremely high and plants matured (i.e. tillered) more rapidly.

Crabgrass cover was rated initially in the severe site on 22 Aug., prior to the time that all three $0.37 \mathrm{~kg} \cdot \mathrm{ha}^{-1}$ sequentials in the LPO timing were applied (data not shown). At this time, commercially acceptable control was observed in the plots treated with $0.56+0.56$ (EPO) and $0.37+0.37+0.37 \mathrm{~kg} \cdot \mathrm{ha}^{-1}(\mathrm{EPO})$ rates (Table 2). Between 22 Aug. and 17 Sept., crabgrass plants had tillered extensively and produced seedheads, and the percent crabgrass cover generally doubled in EPO, MPO, and selected LPO (0.84 and $\left.0.56+0.56 \mathrm{~kg} \cdot \mathrm{ha}^{-1}\right)$ treated plots. Hence, by 17 Sept., the level of crabgrass control was unacceptable in all plots in the severe pressure site as a result of the increasing size of plants that had survived injury from quinclorac. Relatively good control ( $8 \%$ to $9 \%$ crabgrass cover), however, was associated with the $0.56+0.56 \mathrm{~kg} \cdot \mathrm{ha}^{-1}$ (EPO), and $0.37+0.37+0.37 \mathrm{~kg} \cdot \mathrm{ha}^{-1}(\mathrm{EPO})$ rates. In the moderate pressure site there was a rate $x$ timing interaction where all treatments, except $0.84 \mathrm{~kg} \cdot \mathrm{ha}^{-1}(\mathrm{LPO})$, provided acceptable control (Table 2).

The relatively poor level of crabgrass control in the severe site was attributed to a large seed reservoir, more rapid tillering, and the extremely high density of crabgrass plants. It is likely that the greater density of crabgrass plants in the severe site protected the lower canopy shoots, resulting in less contact with quinclorac. Tillering also was more aggressive in the severe site, and these larger plants likely were more resistant to the herbicide. Thus, the less dense (i.e., better quinclorac coverage) and smaller plants in the moderate site were effectively controlled. The only exception was the $0.84 \mathrm{~kg} \cdot \mathrm{ha}^{-1}$ rate in the moderate site, which failed to provide acceptable control in the LPO timing when crabgrass plants had two to three tillers.

In 2002, treatments only were applied MPO to a site with severe crabgrass pressure. The single quinclorac application at $0.84 \mathrm{~kg} \cdot \mathrm{ha}^{-1}$ greatly reduced crabgrass cover, but the level of control was not within the acceptable threshold ( $\leq 5 \%$ crabgrass cover) (Table 2). Unlike 2000 and 2001 , the $0.56+0.56 \mathrm{~kg} \cdot \mathrm{ha}^{-1}$ rate provided excellent control. In 2002, however, the aforementioned sequential rate was applied on a 2-week rather than the 4-week interval used in 2000 and 2001 . The $0.37+0.37+0.37 \mathrm{~kg} \cdot \mathrm{ha}^{-1}$ sequential treatment again provided excellent control. No phytotoxicity was observed in the perennial ryegrass, regardless of year or site.

Bentgrass tolerance to quinclorac. All quinclorac treatments in 2000 discolored the 'Penncross' (Table 3). Quinclorac injury appeared as a foliar chlorosis, but there was no loss of turf density (data not shown). The 0.84 $\mathrm{kg} \cdot \mathrm{ha}^{-1}$ rate applied EPO was the only treatment associated with acceptable color $(>7.5)$ on all dates (Table 3). 'Penncross' treated with quinclorac sequentially at $0.56+0.56$ $\mathrm{kg} \cdot \mathrm{ha}^{-1}$ and $0.42+0.42+0.42 \mathrm{~kg} \cdot \mathrm{ha}^{-1}$ rates in the EPO timing had unacceptable yellowing for 2 weeks ( 6 and 13 July). All treated plots in the EPO timing generally recovered by $2 \mathrm{Aug}$. A reduction in color, however, was observed in 'Penncross' treated with the $0.56+0.56$ or $0.42+0.42+0.42 \mathrm{~kg} \cdot \mathrm{ha}^{-1}$ rates as late as the final rating date ( $8 \mathrm{Sept}$.), when compared to the untreated control.

Quinclorac treatments applied in the MPO timing significantly reduced 'Penncross' color on most dates between 6 July and 2 Aug. (Table 3). Turf treated with $0.84 \mathrm{~kg} \cdot \mathrm{ha}^{-1}$ rate, however, was associated with unacceptable color for only a 2-week period immediately following application. Unacceptable discoloration was associated with sequential quinclorac applications in the MPO timing for 3 weeks between 2 and 23 Aug. All herbicide-treated plots had acceptable color by 8 Sept. On 8 Sept., however, plots treated sequentially with the $0.56+0.56$ or $0.42+0.42+0.42 \mathrm{~kg} \cdot \mathrm{ha}^{-1}$ rates had lower color ratings than the untreated control.

All LPO treatments caused an unacceptable chlorosis for several weeks following application (Table 3). Quinclorac applied once at $0.84 \mathrm{~kg} \cdot \mathrm{ha}^{-1}$ discolored the 'Penncross' unacceptably for nearly 4 weeks ( 2 to 23 Aug.). All sequentially treated 'Penncross' plots had unacceptable color between 17 Aug. and 8 Sept. On the final rating date, turf in all quinclorac-treated plots had reduced color ratings, when compared to the untreated control, especially the sequentially treated 'Penncross' plots.

Quinclorac $\left(0.84 \mathrm{~kg} \cdot \mathrm{ha}^{-1}\right)$ and MSO were applied alone or in combination on 6 July 2000. Initial injury ratings on 11 July, but not 13 July, showed that 'Crenshaw' treated with quinclorac and tank-mixed with MSO initially experienced more injury than quinclorac alone (Table 4). When applied alone, however, MSO did not injure or reduce turfgrass quality. Quality ratings obtained between 18 and 28 July revealed that the chlorosis was not influenced significantly by MSO. Hence, this study demonstrated that quinclorac alone was the primary source of phytotoxicity in creeping bentgrass. Therefore, safeners (i.e. urea- $\mathrm{N}$ or $\mathrm{Fe}+\mathrm{N}$ ) were investigated in 2001 to determine if they would minimize or mask bentgrass injury induced by quinclorac.

Safeners and quinclorac. This study was initiated in the MPO timing on 28 June 2001. This timing was selected because it coincides with the time when crabgrass infestations are most often first discerned by turf managers in the region. In 2000, quinclorac elicited a brilliant foliar chlorosis in the 'Penncross'. By contrast, in 2001 'Crenshaw' did not develop a chlorotic appearance, but injury was detectable for 10 or more weeks in response to selected sequential quinclorac treatments (Table 5). Between 3 July and 8 Aug., the discoloration was uniform and foliage was light-green or slightly yellow, but there was no loss of turf density at this time. Multiple applications of quinclorac alone (i.e. without safeners) often resulted in color ratings below the 7.5 minimum acceptable level. Herbicide injury became most pronounced following a period of supraoptimal temperature stress (average daily high $33{ }^{\circ} \mathrm{C}$ and low $21{ }^{\circ} \mathrm{C}$ ) and $63 \mathrm{~mm}$ of rain between 7 and 12 Aug. These stressful 
Table 3. Fairway height 'Penncross' creeping bentgrass color ratings as influenced by various quinclorac rates and three application timings, 2000.

\begin{tabular}{|c|c|c|c|c|c|c|c|c|c|c|c|}
\hline \multirow{2}{*}{$\begin{array}{l}\text { Quinclorac rate } \\
\left(\mathrm{kg} \cdot \mathrm{ha}^{-1}\right)\end{array}$} & \multicolumn{10}{|c|}{ Turfgrass color, $2000^{z}$} & \multirow[b]{2}{*}{$8 \mathrm{Sept}$} \\
\hline & 6 June & 20 June & 6 July & 13 July & 27 July & 2 Aug. & 9 Aug. & 17 Aug. & 23 Aug. & 30 Aug. & \\
\hline \multicolumn{11}{|c|}{ Early-postemergence timing } & \\
\hline $0.84^{y}$ & $8.9 \mathrm{~b}^{\mathrm{x}}$ & $8.6 \mathrm{c}$ & $8.0 \mathrm{~b}$ & $8.8 \mathrm{a}$ & $9.0 \mathrm{ab}$ & $9.5 \mathrm{a}$ & $9.0 \mathrm{a}$ & $8.8 \mathrm{a}$ & $8.3 \mathrm{a}$ & $9.3 \mathrm{a}$ & $9.3 \mathrm{a}$ \\
\hline $0.56+0.56^{w}$ & $8.9 \mathrm{~b}$ & $9.1 \mathrm{~b}$ & $6.2 \mathrm{c}$ & $6.8 \mathrm{~b}$ & $7.5 \mathrm{c}$ & $8.5 \mathrm{a}$ & $7.7 \mathrm{~b}$ & $7.6 \mathrm{a}$ & $8.2 \mathrm{a}$ & $8.3 \mathrm{~b}$ & $8.5 \mathrm{~b}$ \\
\hline $0.42+0.42+0.42^{\mathrm{v}}$ & $9.0 \mathrm{~b}$ & $8.1 \mathrm{~d}$ & $6.5 \mathrm{c}$ & $7.0 \mathrm{~b}$ & $7.8 \mathrm{bc}$ & $8.6 \mathrm{a}$ & $8.1 \mathrm{ab}$ & $7.5 \mathrm{a}$ & $8.1 \mathrm{a}$ & $8.4 \mathrm{~b}$ & $8.4 \mathrm{~b}$ \\
\hline Untreated & $10.0 \mathrm{a}$ & $10.0 \mathrm{a}$ & $9.7 \mathrm{a}$ & $9.8 \mathrm{a}$ & $9.6 \mathrm{a}$ & $9.6 \mathrm{a}$ & $9.0 \mathrm{a}$ & $7.9 \mathrm{a}$ & $8.1 \mathrm{a}$ & $9.0 \mathrm{a}$ & $9.3 \mathrm{a}$ \\
\hline \multicolumn{12}{|c|}{ Mid-postemergence timing } \\
\hline $0.84^{\mathrm{u}}$ & --- & --- & $6.1 \mathrm{c}$ & $6.8 \mathrm{c}$ & $7.8 \mathrm{~b}$ & $8.7 \mathrm{~b}$ & $8.1 \mathrm{a}$ & $7.6 \mathrm{ab}$ & $8.0 \mathrm{a}$ & $8.6 \mathrm{ab}$ & $8.6 \mathrm{ab}$ \\
\hline $0.56+0.56^{t}$ & --- & --- & $6.7 \mathrm{c}$ & $8.5 \mathrm{~b}$ & $8.4 \mathrm{~b}$ & $6.5 \mathrm{c}$ & $6.9 \mathrm{~b}$ & $7.0 \mathrm{ab}$ & $7.4 \mathrm{ab}$ & $7.7 \mathrm{c}$ & $8.0 \mathrm{~b}$ \\
\hline $0.42+0.42+0.42^{\mathrm{s}}$ & --- & --- & $7.5 \mathrm{~b}$ & $8.5 \mathrm{~b}$ & $8.3 \mathrm{~b}$ & $6.8 \mathrm{c}$ & $7.0 \mathrm{~b}$ & $6.7 \mathrm{~b}$ & $7.1 \mathrm{~b}$ & $8.0 \mathrm{bc}$ & $8.1 \mathrm{~b}$ \\
\hline Untreated & --- & --- & $9.7 \mathrm{a}$ & $9.8 \mathrm{a}$ & $9.6 \mathrm{a}$ & $9.6 \mathrm{a}$ & $9.0 \mathrm{a}$ & $7.9 \mathrm{a}$ & $8.1 \mathrm{a}$ & $9.0 \mathrm{a}$ & $9.3 \mathrm{a}$ \\
\hline \multicolumn{12}{|c|}{ Late-postemergence timing } \\
\hline $0.84^{\mathrm{r}}$ & --- & --- & --- & --- & --- & $6.9 \mathrm{c}$ & $7.0 \mathrm{c}$ & $6.5 \mathrm{bc}$ & $7.0 \mathrm{bc}$ & $8.1 \mathrm{~b}$ & $8.3 \mathrm{~b}$ \\
\hline $0.56+0.56^{q}$ & --- & --- & --- & --- & --- & $7.1 \mathrm{bc}$ & $7.7 \mathrm{bc}$ & $5.9 \mathrm{c}$ & $6.7 \mathrm{c}$ & $6.8 \mathrm{c}$ & $7.1 \mathrm{c}$ \\
\hline $0.42+0.42+0.42^{\mathrm{p}}$ & --- & --- & --- & --- & --- & $7.7 \mathrm{~b}$ & $8.1 \mathrm{~b}$ & $6.8 \mathrm{~b}$ & $7.0 \mathrm{bc}$ & $6.8 \mathrm{c}$ & $7.0 \mathrm{c}$ \\
\hline Untreated & --- & --- & --- & --- & --- & $9.6 \mathrm{a}$ & $9.0 \mathrm{a}$ & $7.9 \mathrm{a}$ & $8.1 \mathrm{a}$ & $9.0 \mathrm{a}$ & $9.3 \mathrm{a}$ \\
\hline
\end{tabular}

${ }^{2}$ Color was assessed visually on a 0 to 10 scale, where $0=$ brown turf, $7.5=$ minimum acceptable level of color for golf fairway turf and $10=$ optimum greenness.

yTreatment was applied 1 June 2000.

${ }^{x}$ Means in the same column within the same application timing followed by the same letter are not significantly different according to Fisher's protected least significant difference $(P \leq 0.05)$.

wreatment was applied 1 and 30 June 2000.

vTreatment was applied 1, 13 and 30 June 2000.

ureatment was applied 30 June 2000.

tTreatment was applied 30 June and 27 July 2000.

sTreatment was applied 30 June, 13 and 27 July 2000.

'Treatment was applied 27 July 2000.

qTreatment was applied 27 July and 10 Aug. 2000.

pTreatment was applied 27 July, 10 and 23 Aug. 2000.

environmental conditions apparently enhanced injury and turf appeared mottled and blotched with a mix of green, yellow, tan and reddishbrown discolored foliage. One possible reason for the difference in injury symptoms between 2000 and 2001 may have been the difference in stand age and cultivar. The 'Penncross' site was 7 years old, whereas the 'Crenshaw' site was $<2$ years old. Because injury no longer influenced just color, overall turfgrass quality (uniform, green color, and density) ratings were used as an additional measure of injury beginning on $13 \mathrm{Aug}$. (Table 6). While some thinning and loss of shoot density $(<2 \%$ thinning) occurred, there was no exposure of bare ground (data not shown).

Plots treated once with quinclorac $(0.84$ $\mathrm{kg} \cdot \mathrm{ha}^{-1}$ ) were discolored unacceptably for one week after treatment ( 3 July), but thereafter, color ratings were generally above the minimum acceptable level (Table 5). Color ratings, however, were worse than the untreated control for three weeks ( 3 to 24 July) following the quinclorac application. Except for the $27 \mathrm{Aug}$. rating, plots treated with the $0.84 \mathrm{~kg} \cdot \mathrm{ha}^{-1}$ rate tank-mixed with $\mathrm{Fe}+\mathrm{N}$ exhibited acceptable color and quality on all dates. Plots treated once with quinclorac $\left(0.84 \mathrm{~kg} \cdot \mathrm{ha}^{-1}\right)$ on $28 \mathrm{June}$ appeared to recover by 30 July. Following the period of environmental stress, however, these same plots as well as others exhibited a reduction in quality (13 to $27 \mathrm{Aug}$.), which probably can be attributed to the herbicide (Table 6). The nature and mechanism of this delayed negative effect due to quinclorac in response to environmental stress is unknown. It seems likely, however, that creeping bentgrass plants may be physiologically stressed by the herbicide for long periods of time. It is unknown if low soil organic matter levels or soil residues of quinclorac contributed to this problem.

'Crenshaw' treated with $0.56+0.56 \mathrm{~kg} \cdot \mathrm{ha}^{-1}$ quinclorac had color ratings similar to turf treated with the $0.84 \mathrm{~kg} \cdot \mathrm{ha}^{-1}$ rate between 3 and 13 July (Table 5). Following the second quinclorac application on 11 July, however, turf color was reduced on several rating dates, when compared to plots receiving $0.84 \mathrm{~kg} \cdot \mathrm{ha}^{-1}$ of quinclorac alone or with urea or $\mathrm{Fe}+\mathrm{N}$ between 21 July and 13 Aug. Furthermore, turf color in plots receiving the $0.56+0.56 \mathrm{~kg} \cdot \mathrm{ha}^{-1}$ rate was below the acceptable threshold on most dates between 3 July and 13 Aug. 'Crenshaw' treated with the $0.56+0.56 \mathrm{~kg} \cdot \mathrm{ha}^{-1}$ rate plus urea had unacceptable color or quality on several dates, especially between 13 and 27 Aug. Conversely, plots treated at this rate with $\mathrm{Fe}+\mathrm{N}$ had acceptable color and quality on nearly all dates between 3 July and 10 Sept. (Tables 5 and 6).

'Crenshaw' color and quality were reduced in plots treated with $0.37+0.37+0.37 \mathrm{~kg} \cdot \mathrm{ha}^{-1}$ of quinclorac alone on all rating dates, when compared to untreated turf (Tables 5 and 6). 'Crenshaw' treated with the $0.37+0.37+0.37$ $\mathrm{kg} \cdot \mathrm{ha}^{-1}$ and $\mathrm{Fe}+\mathrm{N}$, however, had color ratings $\geq 8.1$ on all dates between 3 July and 20 Aug., and color ratings often were similar to the untreated control. Plots treated with sequential quinclorac applications tank-mixed with $\mathrm{Fe}+\mathrm{N}$ generally had better quality than plots treated with same rate of the herbicide alone. Turf quality for plots treated with $0.37+0.37+0.37$ $\mathrm{kg} \cdot \mathrm{ha}^{-1}$ rate plus $\mathrm{Fe}+\mathrm{N}$, however, was inferior to the untreated control on 13 and 27 Aug. The beneficial effects of tank-mixing $\mathrm{Fe}+\mathrm{N}$

Table 4. Injury and quality ratings of Crenshaw creeping bentgrass as influenced by quinclorac and methylated seed oil in 2000 .

\begin{tabular}{|c|c|c|c|c|c|}
\hline \multirow[b]{2}{*}{ Treatment ${ }^{\mathrm{x}}$} & \multicolumn{2}{|c|}{ Injury $^{z}$} & \multicolumn{3}{|c|}{ Quality ${ }^{y}$} \\
\hline & 11 July & 13 July & 18 July & 21 July & 28 July \\
\hline & 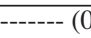 & ale) ------ & ------- & $0-10 \mathrm{sca}$ & \\
\hline Methylated seed oil ${ }^{w}$ & $0.5 \mathrm{c}^{\mathrm{v}}$ & $0.5 \mathrm{~b}$ & $9.5 \mathrm{a}$ & $10.0 \mathrm{a}$ & $9.8 \mathrm{a}$ \\
\hline Quinclorac $75 \mathrm{DG}^{\mathrm{u}}$ & $2.8 \mathrm{~b}$ & $2.9 \mathrm{a}$ & $5.8 \mathrm{~b}$ & $7.9 \mathrm{~b}$ & $8.0 \mathrm{~b}$ \\
\hline Quinclorac $75 \mathrm{DG}+\mathrm{MSO}^{\mathrm{w}}$ & $3.5 \mathrm{a}$ & $3.4 \mathrm{a}$ & $5.4 \mathrm{~b}$ & $7.8 \mathrm{~b}$ & $8.1 \mathrm{~b}$ \\
\hline Untreated & $0.0 \mathrm{c}$ & $0.0 \mathrm{~b}$ & $9.8 \mathrm{a}$ & $10.0 \mathrm{a}$ & $9.8 \mathrm{a}$ \\
\hline
\end{tabular}

${ }^{2}$ Initial injury was rated visually on a 0 to 5 visual scale, where $0=$ no injury and $5=$ entire plot area brown

yTurfgrass quality was assessed visually on a 0 to 10 scale where $0=$ brown or dead turf and 10 $=$ uniform, optimum green color and density.

${ }^{x}$ Treatments were applied 6 July 2000.

"Methylated seed oil (MSO) was tank-mixed at $1 \%(\mathrm{v} / \mathrm{v})$.

"Means in the same column followed by the same letter are not significantly different according to Fisher's protected least significant difference $(P \leq 0.05)$.

"Quinclorac was applied at $0.84 \mathrm{~kg} \cdot \mathrm{ha}^{-1}$. 
Table 5. The influence of urea or chelated iron $(\mathrm{Fe})$ plus nitrogen $(\mathrm{N})$ tank-mixed with quinclorac on the color of fairway height Crenshaw creeping bentgrass in 2001.

\begin{tabular}{|c|c|c|c|c|c|c|c|c|c|c|c|}
\hline \multirow{2}{*}{$\begin{array}{l}\text { Quinclorac rate } \\
\left(\mathrm{kg} \cdot \mathrm{ha}^{-1}\right)\end{array}$} & \multicolumn{11}{|c|}{ Color, $2001^{\mathrm{z}}$} \\
\hline & 3 July & 10 July & 13 July & 21 July & 24 July & 30 July & 3 Aug. & 8 Aug. & $13 \mathrm{Aug}$. & 20 Aug. & $27 \mathrm{Aug}$. \\
\hline & \multicolumn{11}{|c|}{ 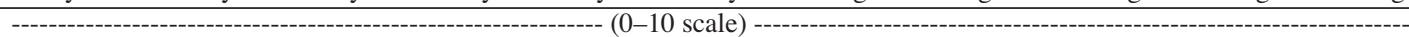 } \\
\hline $0.84^{y}$ & $6.3 \mathrm{f}^{\mathrm{x}}$ & $7.5 \mathrm{e}$ & $7.8 \mathrm{c}$ & $7.8 \mathrm{bc}$ & 7.4 ef & $8.2 \mathrm{~cd}$ & $7.8 \mathrm{de}$ & 8.2 bcd & 7.9 cde & 8.3 cde & $7.8 \mathrm{de}$ \\
\hline $0.84+$ urea $^{w}$ & $6.8 \mathrm{ef}$ & $7.5 \mathrm{e}$ & $7.8 \mathrm{c}$ & $8.0 \mathrm{bc}$ & $7.8 \mathrm{de}$ & $8.3 \mathrm{~cd}$ & $8.1 \mathrm{bcd}$ & 7.9 cde & $7.8 \mathrm{def}$ & $8.4 \mathrm{~cd}$ & $8.0 \mathrm{~cd}$ \\
\hline $0.84+\mathrm{Fe}+\mathrm{N}^{\mathrm{w}}$ & $7.7 \mathrm{~cd}$ & $8.5 \mathrm{abc}$ & $9.4 \mathrm{ab}$ & $9.1 \mathrm{a}$ & $8.9 \mathrm{abc}$ & $9.0 \mathrm{bc}$ & $8.5 \mathrm{bcd}$ & $8.6 \mathrm{~b}$ & $8.5 \mathrm{bc}$ & $9.0 \mathrm{bc}$ & $7.4 \mathrm{def}$ \\
\hline $0.56+0.56^{\mathrm{v}}$ & $6.6 \mathrm{ef}$ & $7.8 \mathrm{de}$ & $7.5 \mathrm{c}$ & $7.0 \mathrm{~d}$ & $6.6 \mathrm{f}$ & $6.8 \mathrm{e}$ & $7.3 \mathrm{ef}$ & $7.2 \mathrm{e}$ & $7.3 \mathrm{efg}$ & $7.7 \mathrm{de}$ & $7.7 \mathrm{def}$ \\
\hline $0.56+0.56+$ urea & $7.1 \mathrm{de}$ & $7.5 \mathrm{e}$ & $8.0 \mathrm{c}$ & $7.3 \mathrm{~cd}$ & $7.5 \mathrm{e}$ & $8.0 \mathrm{~d}$ & $7.9 \mathrm{de}$ & 7.9 cde & $7.1 \mathrm{~g}$ & $7.7 \mathrm{de}$ & $7.2 \mathrm{ef}$ \\
\hline $0.56+0.56+\mathrm{Fe}+\mathrm{N}$ & $8.1 \mathrm{bc}$ & $8.7 \mathrm{abc}$ & $8.8 \mathrm{~b}$ & $7.8 \mathrm{bc}$ & $7.8 \mathrm{de}$ & $9.5 \mathrm{ab}$ & $8.6 \mathrm{~b}$ & $9.4 \mathrm{a}$ & $8.2 \mathrm{~cd}$ & $9.1 \mathrm{~b}$ & $8.0 \mathrm{~cd}$ \\
\hline $0.37+0.37+0.37^{u}$ & $7.1 \mathrm{de}$ & $8.1 \mathrm{~cd}$ & $7.9 \mathrm{c}$ & $7.8 \mathrm{bc}$ & $7.3 \mathrm{ef}$ & $6.4 \mathrm{e}$ & $6.9 \mathrm{f}$ & $7.3 \mathrm{e}$ & $7.3 \mathrm{fg}$ & $7.6 \mathrm{e}$ & $7.2 \mathrm{ef}$ \\
\hline $0.37+0.37+0.37+$ urea & $8.1 \mathrm{bc}$ & $8.4 \mathrm{abc}$ & $8.0 \mathrm{c}$ & $7.6 \mathrm{~cd}$ & $7.5 \mathrm{de}$ & $7.9 \mathrm{~d}$ & 7.9 cde & $7.6 \mathrm{de}$ & $7.5 \mathrm{efg}$ & $7.8 \mathrm{de}$ & $7.0 \mathrm{f}$ \\
\hline $0.37+0.37+0.37+\mathrm{Fe}+\mathrm{N}$ & $8.2 \mathrm{bc}$ & $8.3 \mathrm{bcd}$ & $8.8 \mathrm{~b}$ & $8.4 \mathrm{~b}$ & $8.3 \mathrm{~cd}$ & $9.3 \mathrm{ab}$ & $8.6 \mathrm{bc}$ & $8.1 \mathrm{bcd}$ & $8.4 \mathrm{c}$ & $9.4 \mathrm{ab}$ & $7.8 \mathrm{de}$ \\
\hline Urea $^{t}$ & $8.5 \mathrm{ab}$ & $8.8 \mathrm{ab}$ & $9.9 \mathrm{a}$ & $9.6 \mathrm{a}$ & $9.2 \mathrm{ab}$ & $10.0 \mathrm{a}$ & $9.4 \mathrm{a}$ & $9.6 \mathrm{a}$ & $9.6 \mathrm{a}$ & $9.9 \mathrm{a}$ & $9.1 \mathrm{~b}$ \\
\hline $\mathrm{Fe}+\mathrm{N}^{\mathrm{t}}$ & $8.9 \mathrm{a}$ & $8.8 \mathrm{ab}$ & $10.0 \mathrm{a}$ & $9.4 \mathrm{a}$ & $9.5 \mathrm{a}$ & $10.0 \mathrm{a}$ & $9.5 \mathrm{a}$ & $9.6 \mathrm{a}$ & $9.8 \mathrm{a}$ & $9.9 \mathrm{a}$ & $9.9 \mathrm{a}$ \\
\hline Untreated & $8.5 \mathrm{ab}$ & $9.0 \mathrm{a}$ & $9.1 \mathrm{~b}$ & $9.2 \mathrm{a}$ & $8.6 \mathrm{bc}$ & $8.6 \mathrm{bcd}$ & $8.5 \mathrm{bcd}$ & $8.5 \mathrm{bc}$ & $9.0 \mathrm{~b}$ & $8.8 \mathrm{bc}$ & $8.7 \mathrm{bc}$ \\
\hline \multicolumn{12}{|c|}{ ANOVA } \\
\hline Rate (R) & $* * *$ & $* * *$ & $* * *$ & $* * *$ & $* * *$ & $* * *$ & $* * *$ & $* * *$ & $* * *$ & $* * *$ & $* * *$ \\
\hline Safener (S) & $* * *$ & $* * *$ & $* * *$ & $* * *$ & $* * *$ & $* * *$ & $* * *$ & $* * *$ & $* * *$ & $* * *$ & $* * *$ \\
\hline $\mathrm{R} * \mathrm{~S}$ & NS & $*$ & NS & NS & NS & $* *$ & NS & $* *$ & NS & $* *$ & NS \\
\hline
\end{tabular}

${ }^{2}$ Color was assessed visually on a 0 to 10 scale, where $0=$ brown turf, $7.5=$ minimum acceptable level of color for golf fairway turf and $10=$ optimum greenness.

'Treatment was applied on 28 June 2001.

${ }^{x}$ Means in the same column followed by the same letter are not significantly different according to Fisher's protected least significant difference $P \leq 0.05$ ).

"When a treatment specified tank-mixing with either urea or $\mathrm{Fe}+\mathrm{N}$ an additional urea or $\mathrm{Fe}+\mathrm{N}$ application without quinclorac was made two weeks following the last application and again on 31 Aug. 2001.

'Treatment was applied on 28 June and 11 July 2001.

uTreatment was applied on 28 June, and 11 and 25 July 2001.

'Treatments were applied on 28 June, 11 and 25 July, and 7 and 31 Aug. 2001.

Ns,,$* * * * * * *$ Nonsignificant or significant at the $0.05,0.01$, or 0.001 levels, respectively.

with quinclorac in this study, however, were contrary to a previous investigation reported by Bhowmik and O'Toole, (1991). The main difference in the aforementioned study was that quinclorac was applied in September, when the environmental conditions were probably less stressful.

In 2002, selected quinclorac treatments were assessed in tank-mixes with $\mathrm{Fe}+\mathrm{N}$ to corroborate 2001 findings. Because most discoloration elicited by quinclorac occurred with two or more herbicide applications, only two sequential treatments were assessed. It should be noted that during the study period air temperature exceeded $32^{\circ} \mathrm{C}$ on most days, and turf quality generally was poor and below the acceptable quality level (7.5) for fairways due to heat stress. As was observed in 2000, quinclorac-treated turf developed a brillant chlorosis within 1 week of application. While color and quality ratings were recorded, only quality data are shown (Table 7). Between 17 June and $10 \mathrm{July}$, the addition of $\mathrm{Fe}+\mathrm{N}$ generally improved quality, when compared to plots treated with the same rate of quinclorac alone. The second quinclorac application on 27 June resulted in some reddening and thinning of the turf ( $<2 \%$; data not shown) between 2 and 10 July and all herbicide-treated plots exhibited reduced quality, when compared to the untreated control. Between 19 July and $16 \mathrm{Aug}$., plots treated with $0.56+0.56 \mathrm{~kg} \cdot \mathrm{ha}^{-1}$ rate with $\mathrm{Fe}+\mathrm{N}$ had quality equivalent to the untreated control. Tank-mixing $\mathrm{Fe}+\mathrm{N}$ with the 0.37 $\mathrm{kg} \cdot \mathrm{ha}^{-1}$ rate improved quality, when compared to plots treated with the same rate without the safener between 17 June and 2 July. Following the third application of the $0.37 \mathrm{~kg} \cdot \mathrm{ha}^{-1}$ rate on 8 July, however, no improvement in quality was provided by $\mathrm{Fe}+\mathrm{N}$ until 9 Aug. On the final rating date (16Aug.), plots receiving both herbicide treatments tank-mixed with $\mathrm{Fe}+\mathrm{N}$ had quality equivalent to the untreated control. Conversely, plots treated with quinclorac alone exhibited quality inferior to both the untreated control and their counterpart $\mathrm{Fe}+\mathrm{N}$ treatments. For both sequential rates, tank-mixing quinclorac with $\mathrm{Fe}+\mathrm{N}$ resulted in a level of quality

equivalent to the untreated control during 5 of the 8 weeks of the study.

\section{Conclusions}

Data showed that the best timing to initiate quinclorac applications to effectively control smooth crabgrass in the mid-Atlantic region

Table 6. The influence of urea or chelated iron $(\mathrm{Fe})$ plus nitrogen $(\mathrm{N})$ tank-mixed with quinclorac on the quality of fairway height Crenshaw creeping bentgrass in 2001.

\begin{tabular}{|c|c|c|c|c|c|}
\hline \multirow{2}{*}{$\begin{array}{l}\text { Quinclorac rate } \\
\left(\mathrm{kg} \cdot \mathrm{ha}^{-1}\right)\end{array}$} & \multicolumn{5}{|c|}{ Quality, 2001 z } \\
\hline & 13 Aug. & 20 Aug. & 27 Aug. & 4 Sept. & 10 Sept. \\
\hline & \multicolumn{5}{|c|}{----------------------------- $(0-10$ scale $)$} \\
\hline $0.84^{y}$ & $7.4 \mathrm{de}^{\mathrm{x}}$ & 7.7 cde & $7.4 \mathrm{de}$ & $8.1 \mathrm{cdef}$ & $8.1 \mathrm{bcd}$ \\
\hline $0.84+$ urea $^{\mathrm{w}}$ & $7.5 \mathrm{de}$ & $7.9 \mathrm{bcd}$ & $7.6 \mathrm{~cd}$ & $8.0 \mathrm{cdef}$ & $8.2 \mathrm{bc}$ \\
\hline $0.84+\mathrm{Fe}+\mathrm{N}^{\mathrm{w}}$ & $8.0 \mathrm{~cd}$ & $8.3 \mathrm{bc}$ & $7.3 \mathrm{def}$ & $8.8 \mathrm{bc}$ & $8.6 \mathrm{abc}$ \\
\hline $0.56+0.56^{\mathrm{v}}$ & $6.5 \mathrm{f}$ & 6.9 ef & 6.7 ef & $7.6 \mathrm{ef}$ & $7.3 \mathrm{~d}$ \\
\hline $0.56+0.56+$ urea & $6.5 \mathrm{f}$ & $6.8 \mathrm{f}$ & 6.5 ef & $7.8 \mathrm{ef}$ & $8.1 \mathrm{bcd}$ \\
\hline $0.56+0.56+\mathrm{Fe}+\mathrm{N}$ & $7.5 \mathrm{de}$ & $8.4 \mathrm{bc}$ & $7.3 \mathrm{def}$ & $8.9 \mathrm{~b}$ & $8.8 \mathrm{ab}$ \\
\hline $0.37+0.37+0.37^{\mathrm{u}}$ & $6.3 \mathrm{f}$ & $6.7 \mathrm{f}$ & $6.4 \mathrm{f}$ & $7.5 \mathrm{f}$ & $7.3 \mathrm{~d}$ \\
\hline $0.37+0.37+0.37+$ urea & $6.9 \mathrm{ef}$ & $7.1 \mathrm{def}$ & $6.7 \mathrm{def}$ & 7.9 def & $8.0 \mathrm{~cd}$ \\
\hline $0.37+0.37+0.37+\mathrm{Fe}+\mathrm{N}$ & $7.7 \mathrm{~d}$ & $8.7 \mathrm{~b}$ & $6.8 \mathrm{def}$ & $8.6 \mathrm{bcd}$ & $8.3 \mathrm{bc}$ \\
\hline Urea $^{t}$ & $9.4 \mathrm{a}$ & $9.8 \mathrm{a}$ & $9.1 \mathrm{ab}$ & $9.1 \mathrm{ab}$ & $9.2 \mathrm{a}$ \\
\hline $\mathrm{Fe}+\mathrm{N}^{\mathrm{t}}$ & $9.1 \mathrm{ab}$ & $9.9 \mathrm{a}$ & $9.6 \mathrm{a}$ & $9.8 \mathrm{a}$ & $9.3 \mathrm{a}$ \\
\hline \multirow[t]{2}{*}{ Untreated } & $8.6 \mathrm{bc}$ & $8.6 \mathrm{bc}$ & $8.4 \mathrm{bc}$ & 8.4 bcde & $8.7 \mathrm{abc}$ \\
\hline & \multicolumn{5}{|c|}{ ANOVA } \\
\hline Rate (R) & $* * *$ & $* * *$ & *** $*$ & $* * *$ & $* * *$ \\
\hline Safener (S) & $* * *$ & $* * *$ & NS & $* * *$ & $* * *$ \\
\hline $\mathrm{R} * \mathrm{~S}$ & NS & $*$ & NS & NS & NS \\
\hline
\end{tabular}

${ }^{\mathrm{z}}$ Quality was assessed visually on a 0 to 10 scale, where $0=$ brown or dead turf and $10=$ uniform, optimum green color and density.

yTreatment was applied on 28 June 2001.

${ }^{x}$ Means in the same column followed by the same letter are not significantly different according to Fisher's protected least significant difference $(P \leq 0.05)$.

${ }^{w}$ When a treatment specified tank-mixing with either urea or $\mathrm{Fe}+\mathrm{N}$ an additional urea or $\mathrm{Fe}+\mathrm{N}$ application without quinclorac was made 2 weeks following the last application and again on 31 Aug., 2001.

vTreatment was applied on 28 June and 11 July 2001.

uTreatment was applied on 28 June, and 11 and 25 July 2001.

'Treatments were applied on 28 June, 11 and 25 July, and 7 and 31 Aug. 2001.

ss, ${ }^{*},{ }^{* *}, * * *$ Nonignificant or significant at $P \leq 0.05,0.01$, or 0.001 , respectively. 
Table 7. The influence of chelated iron $(\mathrm{Fe})$ plus nitrogen $(\mathrm{N})$ tank-mixed with quinclorac on the quality of fairway height L-93 creeping bentgrass in 2002.

\begin{tabular}{|c|c|c|c|c|c|c|c|}
\hline \multirow{2}{*}{$\begin{array}{l}\text { Quinclorac rate } \\
\left(\mathrm{kg} \cdot \mathrm{ha}^{-1}\right)\end{array}$} & \multicolumn{7}{|c|}{ Quality, 2002z } \\
\hline & 17 June & 25 June & 2 July & 10 July & 19 July & 9 Aug. & 16 Aug. \\
\hline & ------ & ------- & 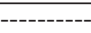 & $(0-10 \mathrm{sca}$ & ------- & 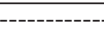 & 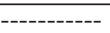 \\
\hline $0.56+0.56^{y}$ & $6.3 b c^{x}$ & $6.3 \mathrm{~d}$ & $5.1 \mathrm{~d}$ & $5.0 \mathrm{c}$ & $6.0 \mathrm{~b}$ & $6.5 \mathrm{c}$ & $6.5 \mathrm{bc}$ \\
\hline $0.56+0.56+\mathrm{Fe}+\mathrm{N}^{\mathrm{w}}$ & $6.5 \mathrm{abc}$ & $7.1 \mathrm{bc}$ & $5.8 \mathrm{bc}$ & $5.9 \mathrm{~b}$ & $6.8 \mathrm{a}$ & $7.1 \mathrm{ab}$ & $7.1 \mathrm{a}$ \\
\hline $0.37+0.37+0.37$ v & $6.1 \mathrm{c}$ & $6.9 \mathrm{c}$ & $5.5 \mathrm{~cd}$ & $5.6 \mathrm{~b}$ & $6.8 \mathrm{a}$ & $6.6 \mathrm{bc}$ & $6.4 \mathrm{c}$ \\
\hline $0.37+0.37+0.37+\mathrm{Fe}+\mathrm{N}^{\mathrm{w}}$ & $6.8 \mathrm{ab}$ & $7.5 \mathrm{ab}$ & $6.3 \mathrm{~b}$ & $6.1 \mathrm{~b}$ & $6.5 \mathrm{ab}$ & $6.9 \mathrm{abc}$ & $7.0 \mathrm{ab}$ \\
\hline \multirow[t]{2}{*}{ Untreated } & $6.9 \mathrm{a}$ & $7.9 \mathrm{a}$ & $7.1 \mathrm{a}$ & $7.1 \mathrm{a}$ & $6.5 \mathrm{ab}$ & $7.3 \mathrm{a}$ & $7.2 \mathrm{a}$ \\
\hline & \multicolumn{7}{|c|}{ ANOVA } \\
\hline Rate (R) & NS & $*$ & NS & $*$ & NS & NS & NS \\
\hline Safener $(\mathrm{S})$ & $*$ & $* *$ & $* *$ & $* *$ & NS & $*$ & $*$ \\
\hline $\mathrm{R} * \mathrm{~S}$ & NS & NS & NS & NS & $*$ & NS & NS \\
\hline \multirow{2}{*}{\multicolumn{8}{|c|}{$\begin{array}{l}{ }^{2} \text { Quality was visually assessed on a } 0 \text { to } 10 \text { scale, where } 0=\text { brown or dead turf and } 10=\text { uniform, optimum } \\
\text { green color and density. } \\
\text { yTreatment was applied on } 12 \text { and } 27 \text { June } 2002 \text {. }\end{array}$}} \\
\hline & & & & & & & \\
\hline \multirow{2}{*}{\multicolumn{8}{|c|}{$\begin{array}{l}{ }^{x} \text { Means in the same column followed by the same letter are not significantly different according to Fisher's } \\
\text { protected least significant difference }(P \leq 0.05) \text {. } \\
\text { w An additional Fe+N application without quinclorac was made on } 19 \text { July } 2002 \text {. }\end{array}$}} \\
\hline & & & & & & & \\
\hline \multicolumn{8}{|c|}{ "Treatment was applied on 12 and 27 June, and 8 July 2002.} \\
\hline
\end{tabular}

was in June (EPO and MPO) prior to crabgrass tillering. Multiple quinclorac applications at 0.37 and $0.42 \mathrm{~kg} \cdot \mathrm{ha}^{-1}$ rates provided better crabgrass control than a single application $\left(0.84 \mathrm{~kg} \cdot \mathrm{ha}^{-1}\right)$ of quinclorac where crabgrass pressure was severe. In the moderately infested site in 2001, however, effective crabgrass control was achieved with $0.84 \mathrm{~kg} \cdot \mathrm{ha}^{-1}$ rate in the EPO and MPO timings. It should be noted that in 2000 and 2001 , the $0.56+0.56 \mathrm{~kg} \cdot \mathrm{ha}^{-1}$ treatment was applied on a 4-week interval, whereas the $0.37+0.37+0.37$ or $0.42+0.42+0.42 \mathrm{~kg} \cdot \mathrm{ha}^{-1}$ treatments were applied on a 2 -week interval. When the $0.56+0.56 \mathrm{~kg} \cdot \mathrm{ha}^{-1}$ rate was applied on a 2-week interval in 2002, excellent crabgrass control was achieved.

Sequential quinclorac applications extended the period of creeping bentgrass discoloration, which apparently was due to heat stress. In 2000, injury was least severe in the EPO timing and most severe in the LPO timing. In 2001, injury was best minimized by tankmixing quinclorac with $\mathrm{Fe}+\mathrm{N}$. While urea generally improved color and quality, it was not as effective as $\mathrm{Fe}+\mathrm{N}$ in masking the discoloration and injury elicited by quinclorac. Bentgrass plots treated with urea or $\mathrm{Fe}+\mathrm{N}$ alone, however, generally exhibited similar color and quality. In 2002, the level of discoloration induced by quinclorac was more severe than in 2001, which may have been due to a prolonged period of supraoptimal temperature stress. Tank-mixing quinclorac with $\mathrm{Fe}+\mathrm{N}$ ameliorated the discoloration on five of eight rating weeks in 2002. Furthermore, tank-mixing quinclorac with $\mathrm{Fe}+\mathrm{N}$ in 2002 resulted in complete recovery of the turf by 9 Aug., whereas turf treated with quinclorac alone continued to exhibit lower quality for an additional three weeks (all data not shown). Therefore, regardless of how often quinclorac is applied to creeping bentgrass, it is advisable to tank-mix $\mathrm{Fe}+\mathrm{N}$ with quinclorac and subsequently apply $\mathrm{Fe}+\mathrm{N}$ about every 2 weeks until the turf has recovered.

\section{Literature Cited}

Bhowmik, P.C. and B.M. O'Toole. 1991. New tools for selective control of crabgrass in cool-season turfgrass. Proc. Northeastern Weed Sci. Soc. 45: 116. (abstr.)

Chism, W.J. and S.W. Bingham. 1991. Postemergence control of large crabgrass (Digitaria sanguinalis) with herbicides. Weed Sci. 39:62-66.

Dernoeden, P.H. and J.M. Krouse. 1990. Maryland smooth crabgrass control evaluations for 1989. Proc. Northeastern Weed Sci. Soc. 44:141-142. (abstr.).

Dernoeden,P.H. 1989. Mature creeping bentgrass and seedling Kentucky bluegrass tolerance to fenoxaprop. Intl. Turfgrass Soc. Res. J. 6:279-283.

Dernoeden, P.H. 2001. Reduced herbicide rates for smooth crabgrass control in the mid-Atlantic region. Intl. Turfgrass Soc. Res. J. 9:1005-1008.
Enache, A.J. and R.D. Ilnicki. 1991. BAS 514 and dithiopyr for weed control in cool-season turfgrasses. Weed Tech. 5:616-621.

Evans, J.R., W.J. Sciarappa, and A.L. Harrell. 1992. Quinclorac for weed control during turfgrass establishment. Proc. Southern Weed Sci. Soc. 45: 134. (abstr.).

Johnson, B.J., 1975. Postemergence control of large crabgrass and goosegrass in turf. Weed Sci. 28: 378-381.

Johnson, B.J. 1994a. Herbicide programs for large crabgrass and goosegrass control in Kentucky bluegrass turf. HortScience 29:876-879.

Johnson, B.J. 1994b. Creeping bentgrass quality following preemergence and postemergence herbicide applications. HortScience 29:880-883.

Martin, D.P. and J.J. Sullivan. 1996. Influence of annual herbicide applications and the environment on smooth crabgrass control. Proc. Northeastern Weed Sci. Soc. 50:114. (abstr.).

Reicher,Z.J., D.V.Weisenberger, and C.S. Throssell. 1999. Turf safety and effectiveness of dithiopyr and quinclorac for large crabgrass control in spring seeded turf. Weed Technol. 13:253-256.

Reicher, Z.J., G.A. Hardebeck, F.F. Yelverton, N.E. Christians, B. Bingaman, and J.Turner. 2002. Tolerance to quinclorac by seedling creeping bentgrass. HortScience 37:210-213.

SAS Institute. 1996. SAS user's guide: Statistics version 6.11. SAS Institute, Cary, N.C.

Sciarappa, W.J. 1991. BAS 514 Approaches to selectivity and efficacy in bentgrass and bluegrass. Proc. Northeastern Weed Sci. Soc. 45: 144 (Abstr.). 